\title{
An Analysis of Embedded Clauses in Sidney Sheldon's "NOTHING LASTS FOREVER" And Their Translation in Indonesian
}

\author{
Adam Anshori \\ English Study Program Diploma 3 \\ Faculty of Psychology and Socio-Cultural Sciences \\ Islamic University of Indonesia
}

\begin{abstract}
This research aims at describing how the English embedded clauses lexicogrammatically realized in the BI version of the novel, to discover the interpretation of the English-BI embedded clause representations in the context of language variations of novel texts, and to count the percentage of each class of English embedded clauses with relative pronouns and their translation in BI.

This research applies a descriptive method. It means that the researcher only collects the data, analyzes them and draws conclusions from the analyzed data. The source of the data consists of the novel Nothing Lasts Forever by Sidney Sheldon and its translation in Indonesian Tiada Yang Abadi by Hendarto Setiadi. A sample of 91 relative pronouns was established using the purposive sampling technique.

The findings of the study show that $89.01 \%$ of the English embedded clauses with relative pronouns are translated into BI relative pronoun yang. There are also English embedded clauses which are translated with BI words other than yang and English embedded clauses with relative pronouns which have no equivalents in Indonesian. Their percentages are $6.59 \%$ and $4.39 \%$.

The English embedded clauses with relative pronouns which are translated into BI words other than yang are classiffed into 3 types. English embedded clauses with relative pronouns translated into 1) conjunction, 2) preposition and 3) other equivalent word in BI. There are also 3 types of English embedded clauses with relative pronouns which have no equivalent in BI. They are 1) English relative pronouns which have no equivalent in BI, 2) English embedded clauses which have no equivalent in BI and 3) The whole sentence which has an English embedded clause in it has no equivalents in BI. The translator may also change the complexity of some sentences by changing complex sentences into compound ones, and thus made them more readable.
\end{abstract}

Key words : embedded clauses, interpretation, Nothing Lasts Forever (Tiada Yang Abadi) 


\section{A. INTRODUCTION}

\section{Background of the problem}

The researcher found various English embedded clauses with relative pronouns in the novel that might be translated into BI in many. ways. Al though relative promouns seem simple, if they are not translated properly into another language, they may have a different meaning in the language. Therefore, it seems necessary to conduct a research describing this kind of problem in the translation of English embedded clauses with relative pronouns in BI.

The researcher's reason for using Sidney Sheldon's Nothing Lasts Forever for the study is that it is a well known novel, and the figure of Sidney Sheldon itself. He has been known among the suspense and intrigue readers as a creative writer that always produces many good stories. Although most of his novels are about intrigue and complicated matters, the language he uses is considered very effective and hot so complicated.

\section{Identification of the Problem}

This study confines itself on the source of the group rank translations involving so called embedded clanses. It focuses its research on the translation of embedded clauses in Fnglish into BI. The topic of the study is how the English embedded clause with a relative pronoun (who, that and which) is translated in BI; the researcher feels trat although such clauses looksimple, in fact there are many kinds or ways they are transiated in BI: The researcher is aware frat many translators mightuse Bl relative pronouns to express the Englishit relative pronouns. Fin this book;, there are many examples of relative pronouns whict actually can be translated in a different way.

.. In this research, dne to his limited time and hanowledge, the researcher fimits the problem only, to the form of Englist embedded clauses, and to focus the research, only three relative promouns are analyzed: who, thatr and which.

\section{Objectives of the Study}

In accordance with the problems formntatedabove, this study intends to:

a) discover how the Enghish embedded clauses are realizedin the Indonesian version of the novel,

b) discover the interpretation of the Englistr-Br embedited clarse representations in the context of language variations of novel texts, and.

c) camtorr the percentage of the classified data:

B.' Theoretical Review

\section{Embedded Clause}

The function of ar embedded clause as an expansion is essentrally to define, delimit or specify. The characteristic of an cmbedded expansinn is the 'defining relotinve clowse'. A relative clanse of this kind is referred to as a DEFINING REI.ATVE CLAUSE. All defining relative clauses are embedded and function as Qualificrin either a nominal or an adverbial group. They contrast with NON-DEFININGREEAITVE CLAUSES, which do not function as Qualiffer and
are not enbedded. 
There is no direct relationship between an embedded clause and the clause within which it is $s_{i}$ embedded; the relationship of an embedded clause to the 'outer'; clause is indirect, with a group as intermediary
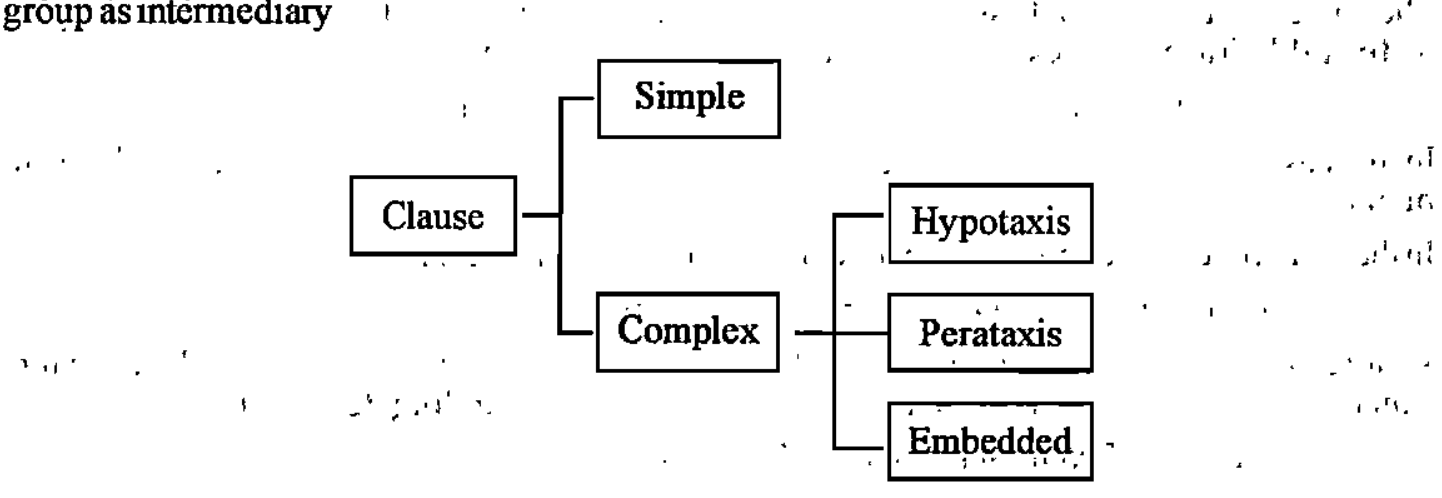

Figure 1. Types of embedding (Halliday)

." In' In his book An Introduction to Functional Grammar, Halliday' (1985: 220) states'that embedded is the 'rank shift' by which a clause comes to function within the structure of a group. It is important to distinguish between embedding on one hand and the tactic relations of parataxis and hypotaxis on the other. Parataxis and hypotaxis are relations between "cláuses; while embedding is not.

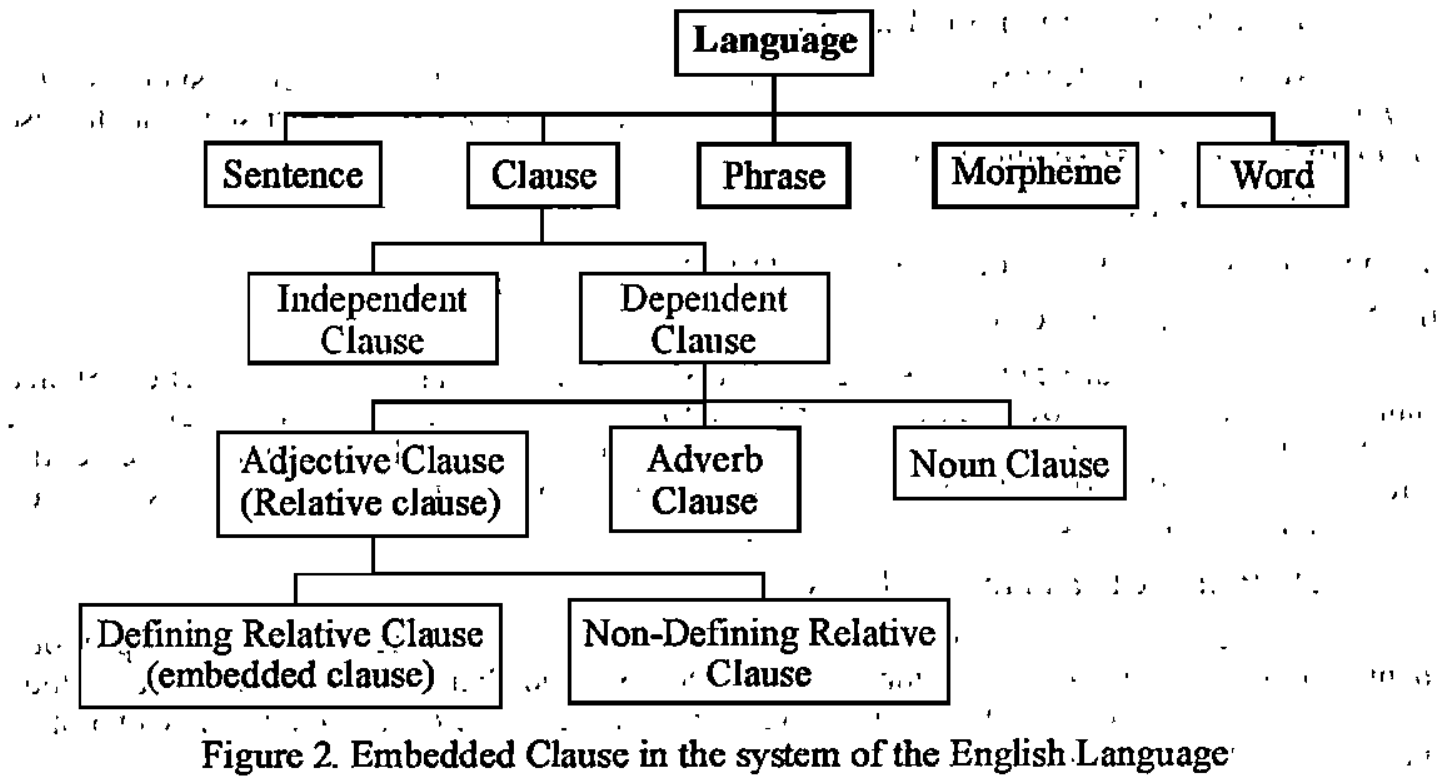
(Halliday)

\section{Relative Pronoun}

A relative pronoun is a pronoun which introduces a subordinate clause and relates to anothèr word or idea in the sentence (Warriners, 1958:73). Harman (1958) defines a relative pronoun "as fóllows: "A relative pronoun performs a dual function in the sentence of which it is a part: it takes a place of a noun in the clause it introduces, and at the same time joins and relates the clause to the rest of the sentence. Take, for example the relstive pronoun which in the sentence 
The book which is lying on the table is Mary's.

The relative pronoun which in the sentence above has an anaphoric reference to the noun phrase (the antecedent) the book, which is post modified by the entire relative clause which is lying on the table. Take, other example the relative pronoun that in the sentence

Bananas that are ripe on the tree are often ruined by insects.

In this case, the relative pronoun that introduces the subordinate clause and relates to the word bananas.

In the meantime, we see an example of relative pronoun in Indonesian:

Orang yang akañ berunding dengan dia belum juga datang.

As a relative pronoun, yang has an anaphoric reference to the noun (the antecedent) orang, which is explained by the whole relative clause yang akan berunding dengan dia.

\section{a). Relative Pronoun in the Relative Clause}

$A$ relative clause is a subordinate clause which gives more information about something or someone mentioned in the main clause. It is introduced by a relative pronoun (House, 1950:56). A relative pronoun is apart of a relativeclause which has functions as a pronoun and as a conjunction relating the clause to the antecedent. In accordance with it, Badudu in Pelik-Pelik Bahasa Indonesia(1982:144) says that a relative pronoun has two functions as follows:

(a) to substitute for a noun in the main clause and

(b) to relate the subordinate clause to the main clause.

\section{b). Relative Pronounsin English}

According to Hornby (1983:156), there are a lot of relative pronouns, such as who, that where, which, and whom. The kinds of relative clauses will be discussed first, before the use of relative pronioun išexplained in detail.

There are two kinds of relative clauses:-

a). defining relative clauses or embedded clauses and

b). Non-defining relative clauses.

A defining relative clause is one that is essential to the meaning of the sentence. Such a clause is not marked off by commas in writing and print A non-defining relative clause is not essential to the meaning of the sentence. The clause gives additional but not $^{2}$ essential information (Hornby, 1983:155). It' is placed between commas. It may also be marked off by means of dashes or places between parentheses.

\section{c). Relative Pronoun in Indonesian}

Indonesian does not have many relative pronouns. In Indonesian, a relative pronoun identically refers to yang. Beside that, Keraf (1980: 69) and Badudu (1981:'144) also include tempat as a relative pronoun. According to Ramlan (1981:56) dimana and darimana cañ be also included as relative pronouns.'

\section{C.Analytical Construct}

Translation is a process of transferring meaning from one language which is known as the source language into another language which is known as the receptor or the target language. In translation, the most important principle is that it is the meaning which should be transferred from the source language into the target language and not the form.

Translation is a process consisting of the reproduction of the source language message. The closest natural equivalent in the receptor language should be first in terms of meaning and 
secondly in terms of style:The main concern of the tranislation process is related to the process of finding the equivalent meaning in the receptor language which may be accompanied by a change of form since there is no one-to-one correlation between form and meaning. One meeaning.can be expressed in various forms and there is also one form, which may have a variety of meanings: This study does not try to examine a theory or a hypothesis, it will instead try to identify and describe the aspects and features of the English embedded clause with relative pronouns and its expression in BI.

As mentioned earlier, there are many ways to express the English embedded clauses with relative pronouns in BI. 'There' are 3 ' classifications usèd to' catègorize them; namely, 1) English'embedded clauses 'with relative pronouns éxpiressed with the BI relative pronour yang; 2) English embedded clauses'with relative pronouns êxpressed with BI wörds other than yang (non-BI relative pronoun); and 3) English èmbedded clauses with rëlative pronouns which have no èquivalent expression in $\mathrm{BI}$.

To find the classification, the researcher must collect data which havè English embèded clausés first and limit the data found to those involving the relative pronouns who; that and which After collecting' the data the researcher also' collects-the expression of the English embedded clauses ' with relative pronouns' -in BL.This 'particular 'study, 'however;' is' mainly concerned with the realization of the expression of relative pronouns in English embedded clauses in BI.

\section{D. iResearch Design}

"This research study išdescriptive qualitative. 'Sütrisno Hadi.(1983:3) writtes "Penelitian ini 'adalah 'suatu' penelitian deskriptif, yaitu' suatu 'penelitian 'dimana' péneliti hanya mengumpulkan data, menganalisa data, dan kemudian menyimpulkan data tañpa menarik kesimpulan yang berlaku secara umum"(This research is a descriptive research, in which the researcher only collected the data, analyzed the data and drew conclusion without making a

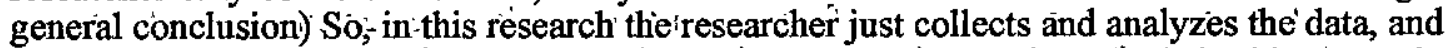
then draws conclusions from the analyzed data:-Thus: there:is no hypothesis in this research! Suharsimi Arikunto (1983: 208) says that "Pada umumnya penelitian deskriptif merupakan penelitian non hypothesis sehingga dalam langkah penelitiannya tidak perlu merumuskan hypothesis". (Generally, descriptive research is a non-hypothethic research, so in the research procedure the researcher need not formulate hypotheses) $b i \cdots$,

This stidy used a content analysis method. According to Krippendorfor (1980:21), content analysis' is a research téchinique for making replicable and valid inferences from data to their context. There are four steps in a content analy sis research! The first step is data making which is divided into unitizing; sampling and recórding. The second step is data redüction; which may be statistical or simply ommision of irrelevant data.-The third'step is' inference. In-this case, the knowledge about the data and their context will influence much in the-success of making inference. The forth step is analysis, which concerns the more conventional processes $s_{j}$ of identification and representation of patterns that are statistically significant

\section{E. Population and Sample $,{ }^{\prime}, w_{1}, i ; \quad, \ldots$,}

In all research, a population which has a close- relationship with the research problems's is needed. According to Singarimbun (1982: 108), population is a whole set of units of analysis whose characteristics can be assured. In this research the population consists of the sentences which were taken from the novel entitled Nothing Lasts Forever in the form of embedded clauses with the relative pronoun (who, that and which) and their translation in BI. 
$\therefore$ The population of research includes all relative pronouns used in the English embedded clauses in Sidney Sheldon's Nothing L'asts Forever and their translation in BI. ,' . Using the purposive sampling technique, the choice of subjects is based on certain characteristics or features which have relevance to the characteristics of the population (Hadi, 1984:82): Here, in this research the researcher intentionally'only focusèd on the relative pronouns used in the defining relative clauses (èmbedded clause.

\section{F. Data Reliability and Validity}

Krippendorf $(1980 ; 155=158)$ states that validity designates the quality of the research results, which lead one to accept them as indisputable facts: The importance of yalidation lies in the assurance it provides that the research findings have been taken seriously in constructing theories or in making decisions on practical issues. Validity is divided into two: internal validity and external validity. In internal validity, the results and the conclusions of study should be verified from two or more sources.

In:this study, the researcher focuses on the internal validity. To reach the internal validity, the researcher asked some observers as his second:observers, that is; those who had the same conclusions or interpretations 'on, the novel related to the English embedded, clauses with the relative pronouns who, that and which and their translation in BI.

\section{G. Techniques of Collecting Data}

The data are collected from Sidney Sheldon's novel Nothing Lasts Forever and its BI version Tiada Yang Abadi. Adepth observation is used in observing every embedded clause with relative pronouns in the English version of novel especially the relative pronouns who, that, and which. After having the findings in the English novel, the researcher collected the translation in $\mathrm{BI}$ version of novel.

\section{H. Data Analysis Technique.}

The data are presented in the form, of written words. The sentences which contain embedded clauses in it need to be identified, delimited, and sorted. The data are classified and set in categories according to the research questions.

\section{Research Findings}

This chapter is concerned with data description and data interpretation., In the data description, the writer will describe the tables which present the results of the analysis related to the research. In the data interpretation, the writer will try to make some generalizations based on the research findings. There is no hypothesis testing since, the writer only tries to identify and find the prominent features that are typical (based on their frequency of occurrence) which often lead to problems of transferring the meaning from English as the source language to BI as the target language as represented in the sample. '1

\section{1:Data Description}

In this study, the writer took the sample from the novel entitled Nothing Lasts Forever by Sidney Sheldon and the BI version of the novel entitled Tiada Yang Abadi. The sample was limited in the form of English embedded clauses. Totally there are 91 idata found in the novel. They are classified based on the relative pronoun used, which include.who, that, and which. 
Tablel.,The Frequency of Occurrence of the English Embedded ${ }_{i}$ Clauses based on

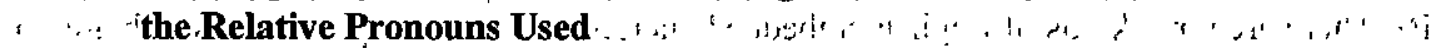

\begin{tabular}{|c|c|}
\hline Relative Pronoun & Frequency of Occurrence. \\
\hline Who & 40 \\
\hline 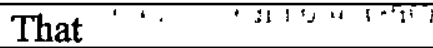 & 50 \\
\hline 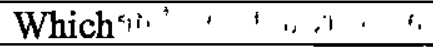 & 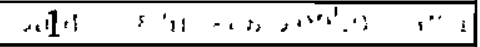 \\
\hline TOTAL & 91 \\
\hline
\end{tabular}

After having the data of the embedded clauses in English, the researcher analyzed each of the data which represent some class used to answer the questions in the problem statement in the Objectives of Study

The collectèd dâtä were classified based on the fơrms of their translation à follows:

1. English' Embedded Clauses with relative pronouns translated into BÎ́ Relative Pronouns yang (class Á)

2. English'Embedded Clauses with relative pronouns translated into BI ther than yang (class B)

3. English Embedded Clauses with rèlative prononus which are not tranislated in BI (class $\mathrm{C}$ )

From all the data there are 81 belonging to class A. In relation to this class, the researcher found thiat there were some sentences which were translated in two sentences in the TL.

Table 2. The Frequency of Occurrence of the Cnglish Relative Pronouns représénted as Indonesian Relátive Pronouns.

\begin{tabular}{|c|c|c|c|}
\hline \multirow{3}{*}{ s } & Relative Pronoun & Class A & \multirow{5}{*}{ 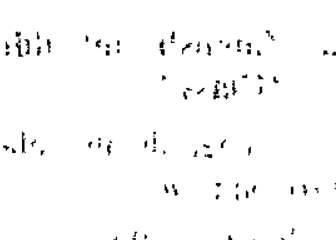 } \\
\hline & Who & 39 & \\
\hline & That & 41 & \\
\hline & 'Which' '" '-' & $1+5+4$ & \\
\hline & TOTAL & 81 & \\
\hline
\end{tabular}

From the collected data ( 6 data), they are three kinds of the translation of relative pronouns found to be translated in $\mathrm{BI}$ as other than yang.

1. There are two relative pronouns translated into conjunctions dan and dengan. (Class B1)

2. There are two relative pronouns translated into the Indonesian prepsition untuk (Class B2)

3. There are two relative pronouns translated into other equivalent word in $\mathrm{B}$ suara and hanya bisa disamai. (Class B3)

Tablè 3. The Frequency of Occurrence of the English Relative Pronoun transiạted into $B I$ other than yang.

\begin{tabular}{|c|c|c|c|c|}
\hline & \multirow{2}{*}{$\begin{array}{l}\text { Rélative } \\
\text { Pronoun }\end{array}$} & \multicolumn{3}{|c|}{$\because$ "Class B } \\
\hline & & Class B1 & Class B2 & Class B3 \\
\hline & $\therefore$ Who , ' & $\therefore 1 \quad+14$ & 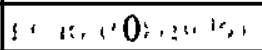 & $-0 ! . \quad 11 . \mathrm{F}$ \\
\hline 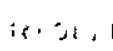 & :That & $1 \because \quad: 111 \cdot \quad \cdots$ & $\div \cdot 1 ! 2: 11 !$ & $\therefore \cdot 2+414$ \\
\hline 4 & Which., ' & $4, .00^{\circ}{ }^{4} \cdot$ & $5 \cdot 0$. & It: $\therefore$ : 0 : \\
\hline & TOTAL & 2 & 2 & $\Rightarrow 12 t^{2} x+1$, \\
\hline
\end{tabular}


'From the data collected, four embedded clauses were paít or whole not translated into BI. There are three kinds of English embedded clauses with relative pronouns; which are not translated into BI. They are .

1. those with english relative pronouns which are not translated into BI (2 data)

2. those with English embedded clauses which are not translated into BI (1 data)

3. those which have an embedded clause in a sentence which are not translated in BI. (1 datum)

Table 4: The Frequency of Occurrence of the English Relative Pronoun' which has no correspondence in $B I$

\begin{tabular}{|c|c|c|c|c|c|}
\hline \multirow[t]{2}{*}{+1} & & \multirow{2}{*}{$\begin{array}{l}\text { Relative" } \\
\text { Pronoun }\end{array}$} & "' Claśs B' & $,^{*}, \ell^{\prime} \cdot 1$, & . \\
\hline & & & Class C1 & Class C2 & Class C3 \\
\hline \multirow{3}{*}{1} & & Who & 0 & .0 & 0 \\
\hline & & That & 2 & 1 & 1 \\
\hline & & Which & .0 & $\therefore, 1: 0$. & 0 \\
\hline & & TOTAL &,$\ldots 2$ & , . $11, x ;$ & $\therefore 1_{11} ;$ \\
\hline
\end{tabular}

\section{Data Interpretation}

Here, the researcher analyzes a number of data representing each class. The data have been classified based on the forms of their translation.

\section{a. English Embedded Clause with Relàtive Pronouns tran'slated in BI Relative Pronouns (Class A)}

Generally, the relative pronouns who, which, and that can be translated into the BI relative pronoun yang.

Below is an illustration of the translation of such relative pronouns:

. 1. You're deffending a cold-blooded killer who murdered a helpless patient for his money. (1/NLF/WO)

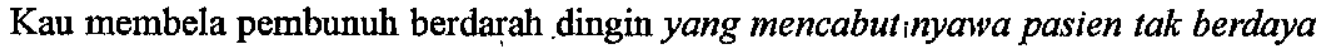
untuk mendapatkan uangnya. (1/TYA/A)

2. The incision was held open by a small retractor which maintained itself in place. $(6 \dot{6} / \mathrm{NLF} / \mathrm{W} \mathrm{W})$

Sayatan itu ditahan retraktor kecil yang tidakperlu dipegang. (66/TYA/A)

3. Paige had been on a thirty-șix-hour shift that had been filled with emergencies. $(73 / \mathrm{NL} / \mathrm{F} / \mathrm{TH})$

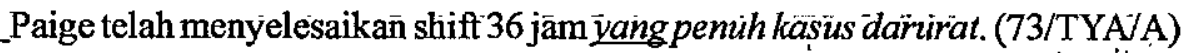

In the translation above, the relative pronouns who, which and that functioning as subject above are in correspondence, with the BI yang which also functions as subject in the BI clause. Who in 1, is to replace people, while which and that in 2. and 3. are to replace things. One more example below shows further analysis. 
4. I was trying to talk to the other lady who lives here. (80/NLF/WO)

Saya sudah berusaha bicara dengan wanita satu lagi yang tinggal disini, tapi dia histeris. (80/TYA/A)

In the example above, the relative pronoun who in the embedded clause who lives here is translated into yang in the embedded clause yang tinggal disini, tapi dia histeris. Here, who and yang modify the object of the main clause the other lady and wanita satu lagi.Other examples :

5. "Laurie and I are the ones who hove been taking care of Mama. (30/NLF/WO)

- Laurie dan aku yangmenguras mama setama ini. (30/TYA/A)

In the example above', the relative pronoun who in the embedded clause who hove been taking care of mama is translated into yang mengurus mama selama ini. Here, who and yang modify the subject of the main clause, Laurie and I and Laurie dan aku.

b. English Embedded Clause with Relative Pronouns translated into BI words other than yang (Class B)

English relative pronouns are probably sometimes translated into BI words other than the relative pronoun yang. They might be translated into a conjunction, preposition,"or other equivalent word in BI. The following illustrates such types of expression.

1. It was an ordinary little bachelor's apartement that desperatelyneeded a woman's touch.

- Apartemen itu khas tempat tinggal bujangan dan memerlukan sentuhan' wanita. . ' 's"

In the example above, the relative pronoun that is translated into BI conjunction dan. The English relative pronoun that is referring to the object "little bachelor's apartement" while the use of conjunction dan in $\mathrm{BI}$ is usually to connect 2 clauses. By using the conjunction dan, the translator changes the English complex sentence (English) into a BI compound sentence, and at the same time he changes the grammatical complexity. This might be more suitable for the BI readers who seem to be younger and thus Iess mature than the English-speaking readers Another example of English relative pronouns which are trànslated into other words (nonIndonesian relative pronouns) are as follows:

2. She was the one who had the extraordinarily high grades and glowing recommendation.

Wallace masih ingat Honey, dokter muda dengan nilai-nilai gemilang dan rekomendasi penuh pujian. (35/TYA/B)

In the example above, the relative pronoun who is translated into another Indonesian preposition dengan. The English relative pronoun who refers to Honey, while the use of the Indonesian conjunction dengan is almost the same with dan. The reason for using the Indonesian conjunction dengan is perhaps the same with that of using the other Indonesian conjunction dan, which is to make it easier for the readers in TL. Beside dan and dengan, there are 3 other words which occur in the findings. These words are also translated in BI not in the form of relative pronouns but as other type of words.

3. ' Code Red is an alert that immediately brings all-out medical assistance to try to'save' the life of a patient. (68/NLF/TH)

$\therefore$ Code Red merúpakan sandi untuk mengerahkan segenap daya medis 'guna ményelamatkan nyäwäpasien. (68/TYA/B)

4. She was awakened by the shrill ringing of a telephone that seemed to be coming from some far-off planet. (53/NLF/TH)

Ia'terbangun karena pesawat teleponnya berdering. Suara itu seakan-akan berasal dari tempat yang jauh sekali. (53/TYA/B) 
5. She had a warm relationship with patients that few of the other doctors had.

Keakrabannya dengan para pasien hanya bisa disamaisegelintir dokter lain.

In these examples, the relative pronoun that is translated into untuk, suara and hanya bisa disamai. The relative pronoun that in that immediately brings all-out medical assistance to try to save the life of a patient. is translated into the preposition untuk in the BI translation untuk mengerahkan segenap daya medis guna menyelamatkan nyawapasien.

The preposition shows the purpose relationship. In this example the context of the sentence remains the same. The relative pronoun that in that seemed to be coming from some faroff planet is translated into suara in the BI translation Suara itu seakan-akan berasal dari tempat yang jauh sekali. Here, the translator divides the sentence in TL into 2 sentences. The relative pronoun that represents the shrill ringing of the telephone and that means the word suara in Indonesian is representative to the condition. The relative pronoun that in that few of the other doctors had is translated into hanya bisa disamai in the $\mathrm{BI}$ translation hanya bisa disamai segelintir dokterlain. The example above shows that the grammatical complexity in BI is low so it is easier to be understood. In other words, the readability in $\mathrm{BI}$ is high. This might be related to. the target readers in BI who may not be very highly educated. This is suitable for the novel which has romance and intrigue of life as the theme. This kind of novel usually has young people as its target readers.

\section{c. English Embedded Clauses with Relative Pronouns which are not translated in BI (Class C)}

Relative pronouns of this class used in the embedded clause are not translated into BI, But not all of the words after the relative pronouns are also translated in BI. The relative pronouns found in the data which are not translated into Indonesian are in the following sentences

1. "She reached down and handed Paige a metal tag that read Paige Taylor,M.D." (12/NLF/TH/8)

Suster Spencer mengambil sebuah papan nama bertulisan'Paige Taylor,M.D.' (12/TYA/C/1)

2. "What the hell can you do for me that you hoven't already done?" Sean said bitterly. (78/NLF/TH)

"Apalagiyang mau kalian lakukan?" balas Sean dengan getir. (78/TYA/C)

If there is no correspondence of the English relative pronoun in $\mathrm{BI}$, it is probably because the English relative pronoun refers to the subject or the object in the sentence. The translator may feel that to avoid repetition, it is unnecessary to translate it in BI.

The English relative pronoun functions as subject to refer to a metal tag: Although the relative pronoun does not correspond in $\mathrm{BI}$ it does not change the meaning or reduce the information from the English novel to the BI readers. While by no representations in BI, it may have different acceptance of the text in the English readers and the BI readers. The BI readers may have feit a reduce of information because of no representations of the English embedded clause and the English sentence in BI novel. This can lead to misinterpretations and misunderstanding of the story in $\mathrm{BI}$ readers.

Based on the analysis the percentage of the forms of the relative pronouns in the English embeded clauses translation in $\mathrm{BI}$ is presented as follows: 
a. English Embedded Clauses with relative pronouns translated into BI relative pronouns yang (class A)

There are 81 data (classA) out of 91 data $=89,01 \%$.

b. English Embedded Clauses with relative pronouns translated into BI other than yarig (class B)

There are 6 data (class B) out of 91 data $=6,59 \%$. They consist of three classes as follows:

a. English relative pronouns translated into dan (conjunction). There are 2 data $=2,19 \%$

b. English relative pronouns translated into untuk and dengan (preposition).' There are 2 data $=2,19 \%$

c." English relative pronouns translated into suara and hanya bisa disamai (reduplication of antecedent). There are 2 data $=2,19 \%$

c. English Embedded Clauses with relative pronouns which are not.translated in BI $\therefore$ (class C).

There are 4 data out of 91 data $=4,39 \%$. They consist of three classes as follows:

. 1). Those which the relative pronoun are not translated in BI. (2 out of 91 data $=2,19 \%$ )

2). Those which the embedded clauses are not translated in BI. (l'out of 91 data $=1,09 \%$ )

3). The whole sentence which has an English embedded clause in it are not translated in BI.(1 out of 91 data $=1,09 \%$

From the theory that has been stated earlier in Chapter II it is stated that the English embedded clauses with the relative pronouns are expressed also into relative pronouns in BI will also take the form of embedded clauses in the BI version. If the relative pronouns in English embedded clauses are expressed not in the form of relative pronouns in $\mathrm{BI}$, the structure also changes. Therefore, class $B$ and class $C$ are not considered as embedded clauses in BI.

- From the findings it can be concluded that most relative pronouns in English embedded clauses are expressed into BI relative pronoun yang. To be more specific, the table below is a summary of the research findings.

Table 5.'The Total Frequency of Occurrence of the'English Embedded

Clauses with the Relative Pronouns who, that and which translated . into BI

\begin{tabular}{|l|c|c|c|c|c|c|c|}
\hline Relative & \multirow{2}{*}{ Class A } & \multicolumn{3}{|c|}{ Class B } & \multicolumn{3}{|c|}{ Class C ' } \\
\cline { 3 - 8 } Pronoun & & B1 & B2 & B3 & C1 & C2 & C3 \\
\hline Who & 39 & 1 & 0 & 0 & 0 & 0 & 0 \\
\hline That & 41 & 1 & 2 & 2 & 2 & 1 & 1 \\
\hline Which & 1 & 0 & & 0 & 0 & 0 & 0 \\
\hline TOTAL & 81 & 2 & 2 & 2 & 2 & $1 \cdot$ & 1 \\
\hline
\end{tabular}

From the table, it can be seen that the most lexicogrammatical relative pronouns are who, that, and which in the English embedded clauses translated into BI relative pronoun yang (ClassA). 


\section{CONCLUSIONS AND SUGGESTIONS}

\section{Conclusions}

Based on the results of the analysis elaborated in the previous chapter, conclusions can be drawn as follows.

1. There are 3 main categories to define the result of the translation in BI. The first is the most commonly found, with the English embedded clause with a relative pronoun translated into an embedded clause too in BI with the indication that the relative pronouns in English are translated in the relative pronoun yang in BI.The second category is of the English embedded clauses with relative pronouns translated in BI words other than yang. In relation to this category, there are 3 types of translation: English embedded clauses with relative pronouns translated into a).conjunction, b).prepotitions and c).other equivalent word in BI. The third category is of the English embedded clauses with relative pronouns which are not translated in BI. In relation to this category there are 3 types: 1). Those which the relative pronoun are not translated in BL. 2). Those which the embedded clauses are not translated in BI. 3) The whole sentence which has an English embedded clause in it are not translated in BI.

2. Most relative pronouns in English are translated into the BI relative pronoun yang. Some pronouns are not translated by $\mathrm{BI}$ relative pronouns since the meaning is considered known from their contexts. In the translating of English relative pronouns, the writer notes that the writer of the book may use other words to replace the regular translation of relative pronouns in BI. This might be related to the target readers in BI which the grammatical complexity in $\mathrm{BI}$ is low so it is easier to be understood. It means the readibility in BI readers is high.

3. ' The findings of the study show that $89,01 \%$ of the English embedded clauses with relative pronouns are expressed into BI relative pronoun (yang) (Class A). There are also English embedded clauses which are expressed in BI words other than yang (non-BI relative pronoun) (Class B) and English embedded clauses with relative pronoun which have no expression in BI (Class C). Their percentages are 6,59\% and 4,39\%. The class B are categorize into 3 types, Enlish embedded clauses with relative pronouns expressed into a). conjunction $(2,19 \%)$, b). prepotition $(2,19 \%)$ and c). other equivalent word in BI $(2,19 \%)$. The class $\mathrm{C}$ are also categorize in 3 types; a).those with the relative pronouns in English which are not translated in $\mathrm{BI}(2,19 \%)$, b). those with the English embedded clause which are not translated in BI $(1,09 \%)$, and c) the whole sentence which has an embedded clause in it are not translated in $\mathrm{BI}(1.09 \%)$.

\section{Suggestions}

Based on theiresearch findings, some suggestions could be given to other researchers who are interested in this field:

1. (the students studying translation). It is suggested that make use of the result of this study as one of the sources of information to enlarge and sharpen their knowledge of translation, especially the translation of English embedded clauses. It should be noted, however, that this study is limited to a certain type of novel. 
2. (translators).This research is expeected to motivate to realize that they should be cautious in translating English embedded clauses. They should consider that not every relative pronoun in English embedded clauses may be translated into relative pronouns in BI.

3. Finally, (other researchers) it is suggested that conduct a further research related to this study with a wider scope. Since the study only covers the translation of English embedded clauses, and especially the relative pronouns, it is suggested that they conduct an analysis of translation of English embedded clauses with a scope concerning other relative pronouns.

\section{BIBLIOGRAPHY}

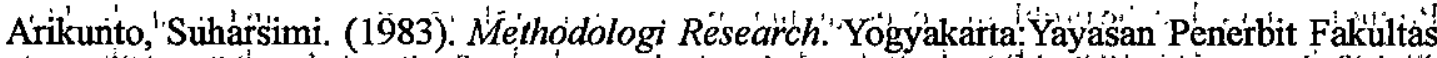
'Psikológi UGM.

Arikunto, Suharsimi. (1983). Prosedur Penelitian: Pendekatan Praktek. Jakarta: PT.Bina Aksara.

Badudu, J.S. (1982). Pelik-Pelik Bahasa Indonesia. Bandung: CV Pustaka Lima.

Brislin, Richard W. (1976). Translation Application and Research. New York: Gradener Press.

Forlini, Gary. (1987). Grammar and Composition. Englewood Cliffs, Nèw: Jèrsey: PrenticeHall, Inc!

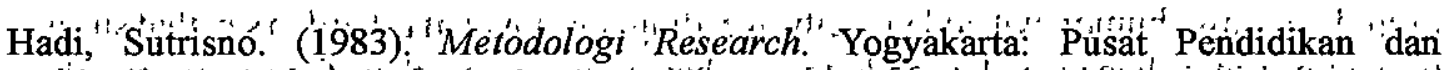

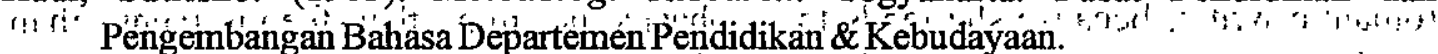

Halliday, MA.K. (1985) AnIntroduction to Functional Grammar London, Edward Arnold

Hornby,A.S : (1983). A Guide to Patterns and Usage in English. London: Oxford University

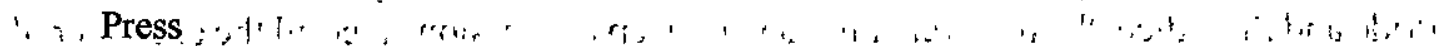

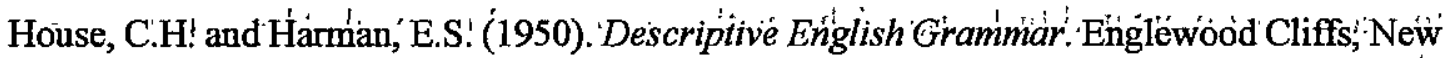
Jersey: Prentice Hall Inc.

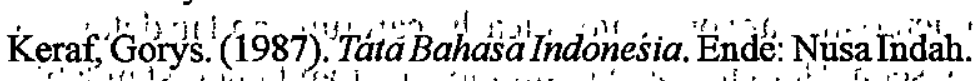

Krippendorff, $\mathrm{K}$ (1980) Content Analysis: An Introduction, to its Methodology: London: Sage Publication.

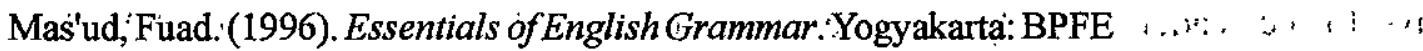

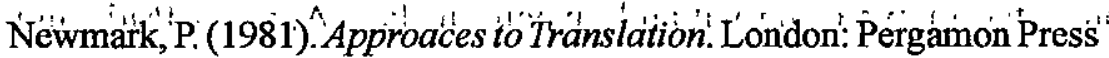

Newmark, P. (1988). A Textbook of Translation. London: Prentice Hall International

Nida, Eugene and Taber, Ch. (1974). The Theory and Practice of Transtation.:Leiden, The ; ,1. United Bible Societies, ; ;

Ramilan, M!(1987): Sintálasis: Yogyakarta: CV. Karyonò

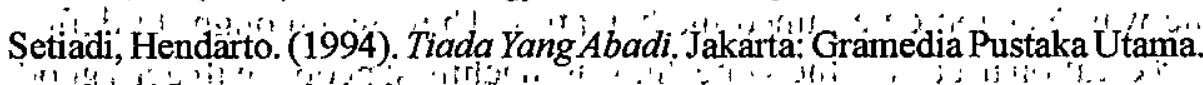
Sheldon, Sidney. (1994). Nothing Lasts Forever. New York: Warner Books.Inc.

Singarimbun, Masri. (1982).Metode Penelitian Survei. Jakarta: LP3ES 